[Miscellaneous Note]

\section{First record of the genus Heterakis (Nematoda: Heterakidae) obtained from two scarce avian species, Japanese rock ptarmigan (Lagopus mutus japonicus) and Okinawa rails (Gallirallus okinawae), in J apan}

\author{
Tomoo Y oshino ${ }^{1}$, M anabu Onuma², \\ Takashi Nagamine ${ }^{3}$, Mako Inaba², \\ Takaharu Kawashima², Koichi Murata ${ }^{4}$, \\ Kazuto Kawakami ${ }^{5}$, T akashi Kuwana ${ }^{2}$ \\ and M itsuhiko A sakawa ${ }^{1,6}$
}

The Japanese rock ptarmigan (Lagopus mutus japonicus) and the Okinawa rail (Gallirallus okinawae) are endangered avian species in Japan, and both have been given the status of National Natural Treasures by the Japanese Government. In the last decade, a decline in these species has been observed because of artificial developments, traffic accidents, and/or predation by feral cats and the invasive alien species: the feral small A sian mongoose (Herpestes javanicus). A ccordingly, several conservation projects including rehabilitation and translocation of rails that had under-

'Department of Pathobiology, School of V eterinary M edicine, Rakuno Gakuen University, Ebetsu, Hokkaido 069-8501, Japan.

${ }^{2}$ Biological Resources and Informatics Laboratory, Laboratory of Intellectual Fundamentals for Environmental Studies, National Institute for Environmental Studies, T sukuba, Ibaragi 305-8506, Japan.

${ }^{3}$ Nagamine A nimal Clinic, Gushi-gawa, Okinawa 904-2235, Japan.

${ }^{4}$ College of Bioresource Sciences, Nihon University, Fujisawa, Kanagawa 252-8510, Japan.

${ }^{5} \mathrm{~T}$ ama Forest Science Garden, Forestry and Forest Products Research Institute, Hachioji, T okyo 193-0843, Japan. 6Corresponding author, e-mail: askam@ rakuno.ac.jp gone treatment for injuries or diseases have been implemented by the Japanese Government. Despite these efforts, the pathogenic or parasitic agents of this rail species have rarely been described, and especially, no parasitic nematodes of these rails have so far been recorded.

In undertaking a conservation project whereby wild birds are returned to a free-living condition, it is important to carry out a health risk assessment (Leighton, 2002) to ensure that changes in host-parasite encounters brought about by the move do not result in harm through parasitic disease outbreaks. In the risk assessment process, it is thus essential to determine the parasitic agents of the species. This paper reports, for the first time, on the genus Heterakis (Nematoda: Heterakidae) obtained from both avian species.

Japanese Rock Ptarmigans:

In February, 2002, two rock ptarmigans were captured in Mt. Tateyama, Japan $\left(36^{\circ} 35^{\prime} \mathrm{N}\right.$, $137^{\circ} 36^{\prime} \mathrm{E}$ ), and the birds had been kept in Ueno Zoological Garden, Tokyo, from then to 2003. However, these ptarmigans died due to an unknown cause (probably, non-infectious diseases), and a post-mortem examination was performed. During the examination, one male and one female in total of the parasitic nematode genus Heterakis were obtained from the large intestinal tract of one individual of the two examined.

Okinawa Rails:

From 15 M ay to 26 June 2004, six dead rails seemingly killed in traffic accidents in the northern part of Okinawa Island, Japan $\left(26^{\circ} 45^{\prime} \mathrm{N}\right.$, $128^{\circ} 15^{\prime} \mathrm{E}$ ), were taken to the Laboratory of Intellectual Fundamentals for Environmental Studies, the National Institute of Environmental Studies, Japan, for inclusion in the Environmental Specimen Time Capsule project (www.nies. go.jp/index-j.html). The carcasses were stored at $+4^{\circ} \mathrm{C}$ until post-mortem examina- 
tion. During the examination, a total of nine individual parasitic nematodes of the genus H eterakis w ere obtained from the large intestinal tracts of three of the rails examined. Between two and five nematodes were counted in each rail.

Nematode specimens:

The nematodes obtained were examined morphologically in lacto-phenol solution, and measurements were accomplished with the aid of a camera lucida. The nematode specimens from the ptarmigan (specimen No.: WAMC-As8864-1) and from the rails (specimen Nos.: NIES15A-1, 16A-1, 19A-1) have been deposited in the Wild A nimal Medical Center, Rakuno Gakuen University, and in the Laboratory of Intellectual Fundamentals for Environmental Studies, the National Institute for Environmental Studies, Japan, respectively.

Although only one male was obtained from the ptarmigan (Fig. 1), it was identified as the cosmopolitan species $\mathrm{H}$. gallinarum, because of the spicule length (right spicule $=1.647 \mathrm{~mm}$, left one $=0.475 \mathrm{~mm}$ ) and arrangement of the caudal papillae of the male individual present (Inglis, 1967; Skrjabin et al., 1961). On the other hand,

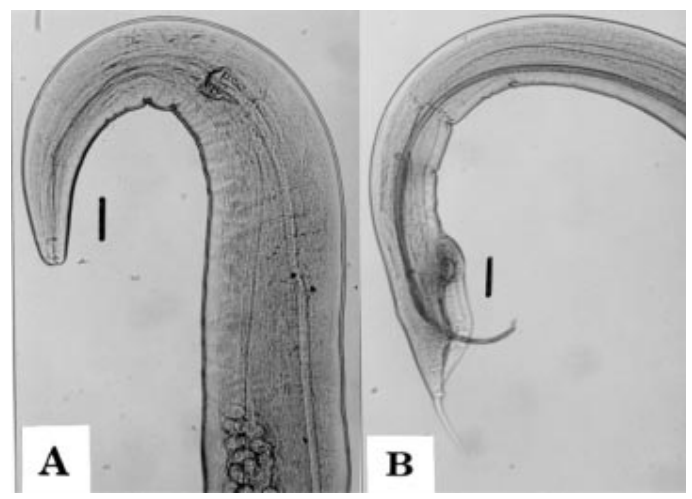

Fig. 1. Heterakis gallinarum from Lagopus mutus japonicus. A : A nterior extremity of female, left lateral view. B: Posterior extremity of male, right lateral view. Scale bars $=0.1 \mathrm{~mm}$.

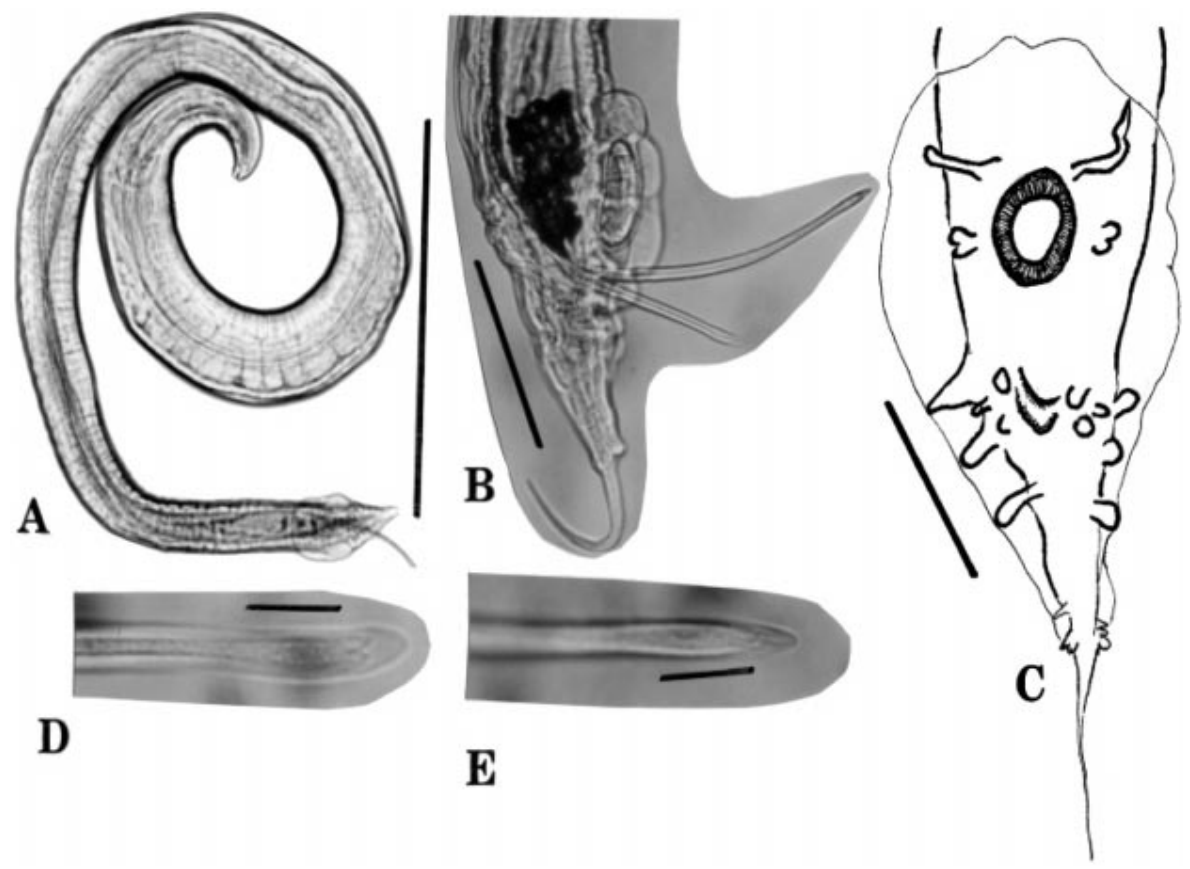

Fig. 2. Males of Heterakis isolonche from Gallirallus okinawae. A: Whole body, ventral view, scale bar $=1.0 \mathrm{~mm}$. B and C: Posterior extremity of body, right-lateral $(B)$ and ventral views $(C)$, scale bars $=0.1 \mathrm{~mm}$. $D$ and $E: T$ ips of spicules, right $(D)$ and left $(E)$ ones, scale bars $=0.01$ $\mathrm{mm}$. 
the species from the rails (Fig. 2) is different from $\mathrm{H}$. gallinarum, because of the presence of two equal spicules. A ccording to taxonomical reviews and/or keys of the genus Heterakis (Chabaud, 1978; Inglis, 1967, 1991; Inglis et al., 1971; Skrjabin et al., 1961), there is only one known species of Heterakis with two equal or nearly equal spicules between 1.3 and $2.3 \mathrm{~mm}$ in length of the present specimens ( $T$ able 1), namely $\mathrm{H}$. isolonche [Synonyms: $\mathrm{H}$. lanei, $\mathrm{H}$. neoplastica; Host genera: Crossopt, Gennaeus, Ithagenes, Lophophorus, Lophura, Phasianus, Polyplectron, Thaumalea; Localities (including zoological gardens): Europe, India, China, USA ], and the nematodes from the rails belonging to this species.

Hetrakis gallinarum inhabits the poultry's caecum and is important as the transport host for the highly pathogenic protozoan Histomonas meleagridis that causes an often-fatal disease for many birds, blackhead disease (M cDougald, 2005; Chalvet-Monfray et al., 2004). Moreover, larvae of $H$. gallinarum can cause typhlitis with severe diarrhea, weight loss and depression with lymphocytic infiltration and granuloma formation by invading the intestinal wall of infected birds (M cDougald, 2005; Chalvet-Monfray et al., 2004). Hence, the nematodes of the genus Heterakis should be taken into epidemiological consideration, although no pathogenicities regarding $\mathrm{H}$. isolonche have so far been reported.

\section{ACKNOW LEGDE MENT}

The present survey was supported in part by both a Grant-in-Aid (Nos. 16510179, 18510205) from the Ministry of Education, Science and Culture of Japan, and the Global Environment Research Fund (F-062) from the Ministry of the Environment of Japan.

\section{LITERATURE CITED}

Chabaud, A. G. (1978) Keys to genera of the superfamilies Cosmocercoidea, Seuratoidea,

Table 1. Measurements of Heterakis isolonche from Gallirallus okinawae. (in $\mathrm{mm}$ )

\begin{tabular}{|c|c|c|}
\hline & Mature males $(\mathrm{N}=3)$ & Immature male $(\mathrm{N}=1)$ \\
\hline Body length & $\begin{array}{lll}3.2 & -4.9 & (4.10)^{1}\end{array}$ & 4.8 \\
\hline width & $0.17-0.21(0.190)$ & 0.14 \\
\hline Esophagus length & $0.53-0.64(0.596)$ & 0.69 \\
\hline Nerve ring from head end & $0.14-0.22(0.184)$ & 0.31 \\
\hline Excretory pore from head enc & nd $0.25-0.28(0.263)$ & $\overline{\overline{ }}$ \\
\hline Spicules length & $1.3-2.3$ & 0.31 \\
\hline Sucker in diameter & $0.058-0.064$ & 0.064 \\
\hline \multirow[t]{2}{*}{ Cloaca from tail end } & 0.17 & $\overline{\overline{ }}$ \\
\hline & M ature females $(\mathrm{N}=2)$ & Immature females $(\mathrm{N}=3)$ \\
\hline Body length & 4.9 and 5.6 & $2.7-4.1 \quad(3.41)$ \\
\hline width & 0.17 and 0.23 & $0.13-0.17(0.158)$ \\
\hline Esophagus length & 0.62 and 0.67 & $0.51-0.77(0.610)$ \\
\hline Nerve ring from head end 0 . & 0.39 and 0.41 & $0.17-0.31(0.221)$ \\
\hline Excretory pore from head enc & nd 0.256 & $0.24-0.26(0.250)$ \\
\hline Vulva from tail end & 0.241 & $1.3-2.0 \quad(1.67)$ \\
\hline Vestibule & 0.62 & \\
\hline Tail length & 0.35 and 0.44 & 0.19 and 0.34 \\
\hline \multicolumn{3}{|c|}{ Egg size $(\mathrm{N}=8) \quad 0.057-0.067(0.0625) \times 0.034-0.042(0.0370) \overline{\overline{ }}$} \\
\hline
\end{tabular}


Heterakoidea and Subuluroidea. $\mathrm{CIH}$ Keys to the Nematode Parasites of $V$ ertebrates. No. 6, Commonwealth Agricultural Bureaux, UK, pp. 71.

Chalvet-M onfray, K., Sabatier, P., Chauve, C. and Zenner, L. (2004) A mathematical model of the population dynamics of Heterakis gallinarum in turkeys (M eleagridis gallopavo). Poultry Science 83, 1629-1635.

Inglis, W. G. (1967) The evolution, host relationships and classification of the nematode superfamily Heterakoidea. Bulletin of the British Museum-Natural History 15, 3-28.

Inglis, W. G. (1991) A revision of the nematode genus Odontoterakis Skrjabin \& Schikhobalova, 1947 (Heterakoidea). Systematic Parasitology 20, 69-79.

Inglis, W. G., Schmidt, G. D. and Kuntz, R. E. (1971) Nematode parasites of Oceanica. XII.
A review of $\mathrm{H}$ eterakis species, particularly from birds of Taiwan and Palawan. Records of the South A ustralian Museum 16, 1-14.

Leighton, F. A . (2002) Health risk assessment of the translocation of wild animals. Review of Scientific T echnology (OIE) 21, 187-195.

McDougald L. R. (2005) Blackhead disease (histomoniasis) in poultry: a critical review. A vian Diseases 49, 462-76.

Skrjabin, K. I., Shikhobalova, N. P. and Lagodovskaya, E. A . (1961) Oxyurata of animals and man. Part 2. (Skrjabin, K. I. ed.), Essentials of Nematodology. Translated from Russian. Israel Program for Scientific Translations, Israel, pp. 703.

Received December 31, 2008 